José Domingo Peñafiel

\title{
Casa en Mallarauco
}

La casa se emplaza en una parcela al centro del valle de Mallarauco, teniendo la vista limitada por los cerros bajos de la cordillera de la costa.

Se trata de una casa con algunas semejanzas a la antigua casa de campo de la zona central. Los materiales son los tradicionales: muros blancos, techos de tejas, aleros de madera, pisos de cerámica, ventanas de madera. Sin embargo, el modo de abordar el proyecto es nuevo y las formas resultantes son diferentes a las tradicionales. La casa se dispone paralela a los cerros dominantes. Los recintos habitables; dormitorios y recibos se disponen al norte y al oriente. Por el sur y el poniente, la casa está envuelta por un corredorgalería que remata en un extremo como cocina, y en el otro extremo como sala de estar.

Los espacios habitables son ortogonales, pero el corredor-galería y el alero-terraza rompen la ortogonalidad con líneas inclinadas que transforman estos recorridos en paseos orientados a los cerros y al paisaje.

\section{José Domingo Peñafiel}

Arquitecto, Pontificia Universidad Católica de Chile, 1975. Ha desarrollado proyectos de casas, edificios de vivienda y oficinas, industrias, diseño de muebles, escenografías, escultura y pintura. Durante 2002 se ha desempeñado muebles, escenografias, escultura y pintura. Durante 2002 se ha dese
como profesor de titulación en la Escuela de Arquitectura P.U.C.
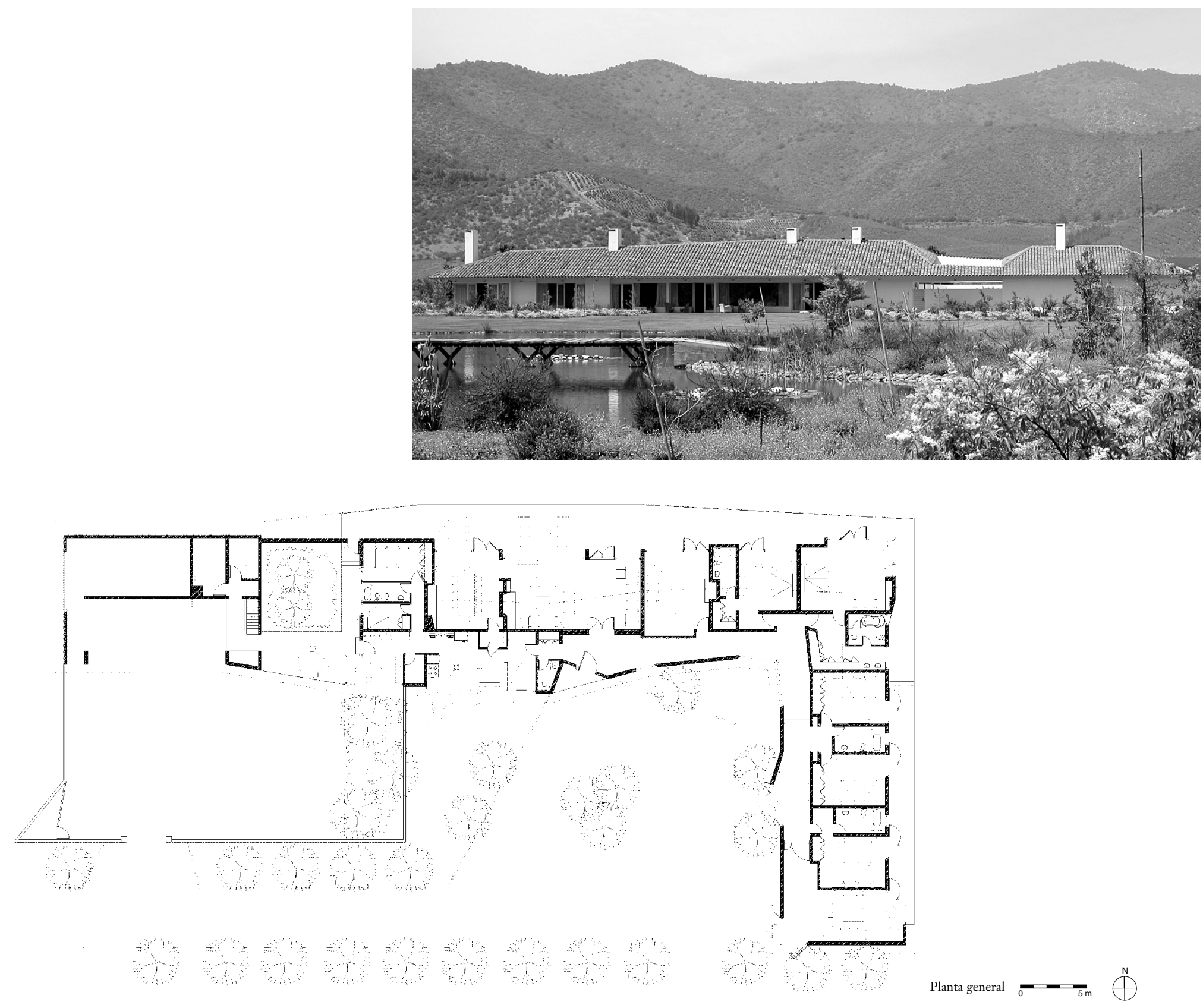

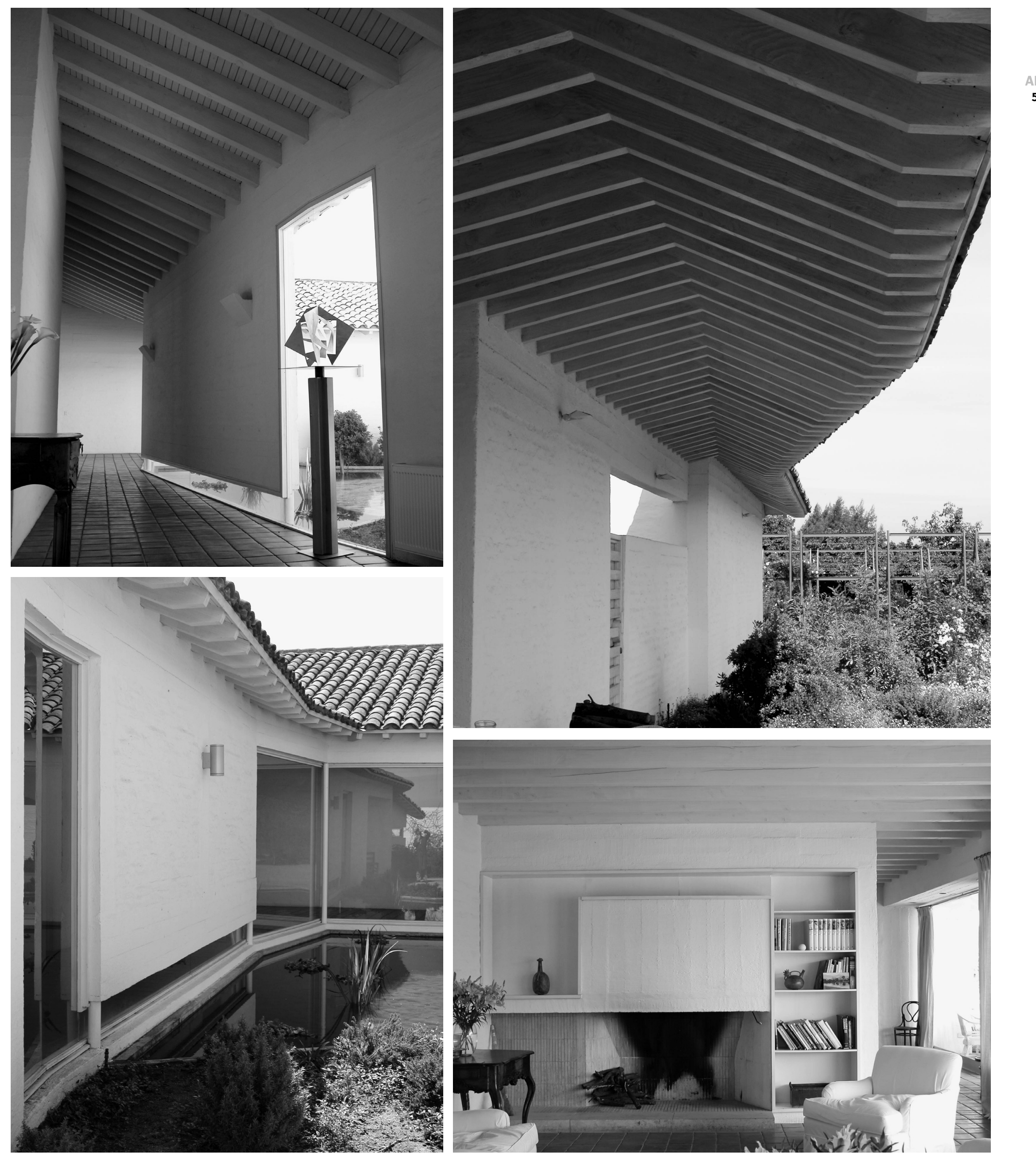